\title{
Geochronology and Tectonic Evolution of the Lincang Batholith in Southwestern Yunnan, China
}

\author{
Hongyuan Zhang, ${ }^{1,2}$ Junlai Liu, ${ }^{1,2}$ and Wenbin $\mathrm{Wu}^{2}$ \\ ${ }^{1}$ State Key Laboratory of Geological Processes and Mineral Resources, China University of Geosciences, Beijing 100083, China \\ ${ }^{2}$ Faculties of Earth Sciences and Resources, China University of Geosciences, Beijing 100083, China
}

Correspondence should be addressed to Hongyuan Zhang, zhang-hong-yuan@263.net

Received 15 February 2012; Accepted 5 April 2012

Academic Editor: Quan-Lin Hou

Copyright ( $\odot 2012$ Hongyuan Zhang et al. This is an open access article distributed under the Creative Commons Attribution License, which permits unrestricted use, distribution, and reproduction in any medium, provided the original work is properly cited.

Geochronological research of the Lincang Batholith is one key scientific problem to discuss the tectonic evolution of the Tethys. Two granitic specimens were selected from the Mengku-Douge area in the Lincang Batholith to perform the LA-ICPMS Zircon U-Pb dating based on thorough review of petrological, geochemical, and geochronological data by the former scientists. Rock-forming age data of biotite granite specimen from Kunsai is about $220 \mathrm{Ma}$, the Norian age. However, the west sample from Mengku shows $230 \mathrm{Ma}$, the Carnian age. The later intrusion in Kunsai area located east to the Mengku area shows directly their uneven phenomena in both space and time and may indirectly reflect the space difference of the contraction-extension transformation period of the deep seated faults. Considering the former ${ }^{40} \mathrm{Ar} /{ }^{39} \mathrm{Ar}$ data and the outcrop in Mengku, the Lincang Batholith should have experienced one tectonic exhumation and regional subsidence cycle. The regional subsidence cycle has close relations to the expansion of the Meso Tethys.

\section{Introduction}

The Sanjiang-Indochina region is one key area to study the evolution of the Tethys [1-10] (Figure 1). The ChangningMenglian zone was considered as the major faunal break between Gondwanan assemblage to the west and Cathaysian to the east $[11,12]$. The subduction-related magmatism occurred along the western edge of the Lanping-SimaoIndochina terrane throughout the Triassic and the closure of Palaeo-Tethys $[12,13]$. The Lincang Batholith extends $\sim 370 \mathrm{~km}$ from north to south, covering the ChiangraiChiang Mai region of Thailand, with an area of more than $10000 \mathrm{~km}^{2}$ (Figure 2). It has been shown by many authors that there is great mineral potential [14].

The Lingcang Batholith was divided into three lithologic intervals by previous authors, the Xiaojie, Lincang, and Menghai intervals (Figure 2) [15-17]. The major intrusion is porphyritic monzonitic granite, which mainly contains quartz, zonal plagioclase, $\mathrm{K}$-feldspar, and biotite. In addition, geochemical studies have shown that the granite mainly has source features of the crust mixing origin $[16,18]$.
The Lingcang Batholith was proposed to form in a passive continental margin according to geochemical research [19]. The intrusive timing spans from late Permian to late Triassic based on whole-rock $\mathrm{Rb}-\mathrm{Sr}$, mineral ${ }^{40} \mathrm{Ar} /{ }^{39} \mathrm{Ar}$, whole-rock ${ }^{87} \mathrm{Sr} /{ }^{86} \mathrm{Sr}, \mathrm{Rb}-\mathrm{Sr}, \mathrm{Sm}-\mathrm{Nd}$, and some other methods (Table 1).

But there are also some understanding differences on the crystallization period and evolution time of the Lincang Batholith. Many predecessors discussed mineral diagenesis and tectonic evolution through traditional data $[16,20]$, although, not from the viewpoint of the plate tectonics. On scientific problems of the Lincang Batholith, some solutions were put forward such as single period of mixed granite [16], quasi-situ metasomatic granite [20], or Neoproterozoic type I granite complex batholith with multiperiod transforming events [19].

Therefore, the formation and evolution of the Lincang Batholith is still the key to discuss the regional tectonic evolution of the Baoshan and Lanping-Simao-Indochina block. In this study, we conducted petrographic analysis of the Lincang Batholith and provide new LA-ICP-MS U$\mathrm{Pb}$ data in order to constrain the tectonic evolution of the 


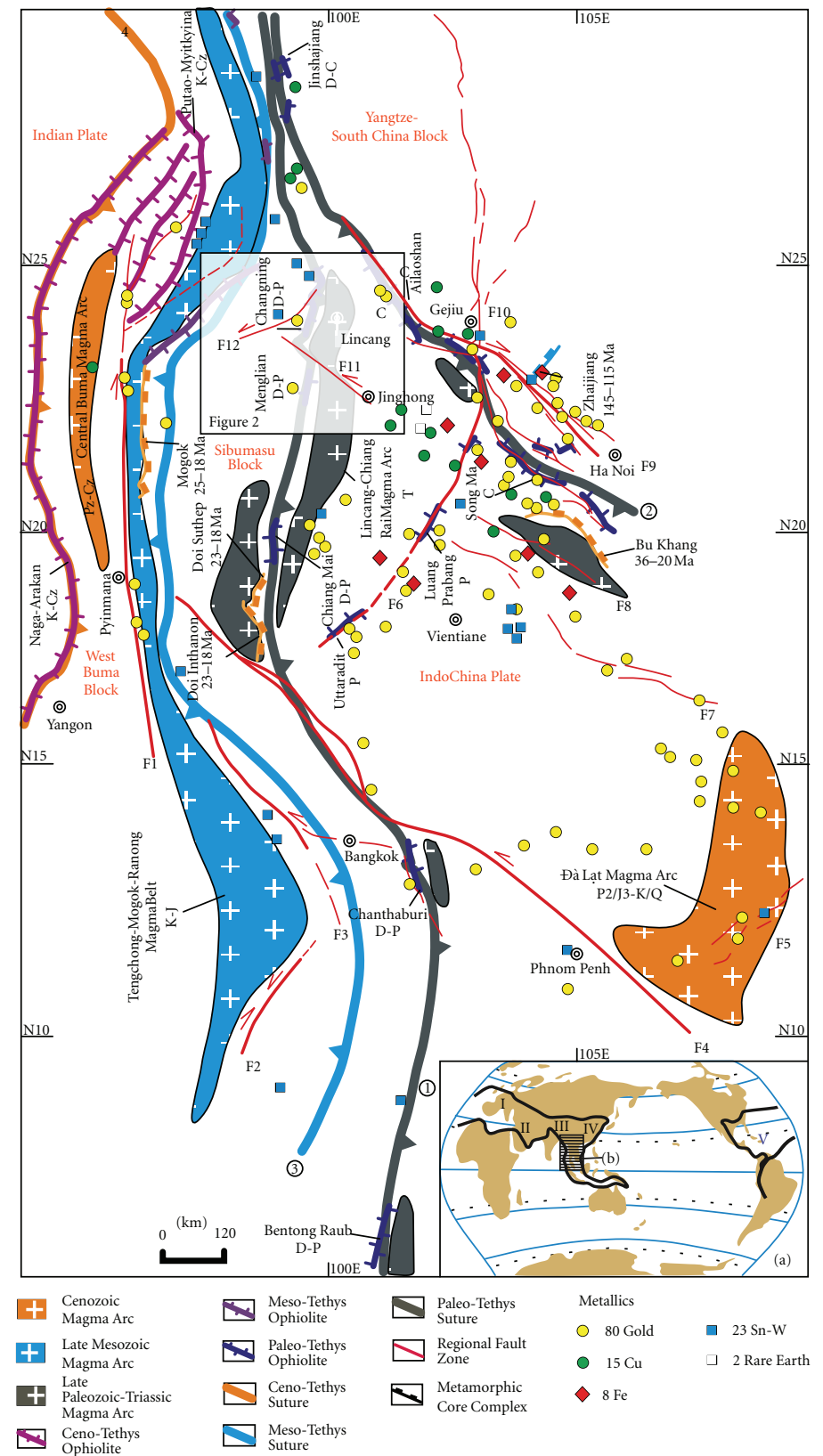

Figure 1: Map of plate tectonics and ore-forming metals in the southern Sanjiang and Indochina peninsula. (a) Scope of Tethys and zone divisions; (b) research area and distribution of major metals: (1) Changning-Menglian-Chiangmai PaleoTethys Suture (time and space after $[1,21,22]$ ); (2) Ailaoshan-Song Ma Paleo-Tethys Suture (time and space after [2, 6, 8]); (3) Bangong Co-Nujiang Meso-Tethys Suture (time and space after [5]); (4) Yanlung Tsangpo-Naga-Arakan New-Tethys Suture (time and space after [22, 23]); (F1) Nujiang-Saging Fault Zone; (F2) Ranong Fault Zone; (F3) Three Tower Fault Zone; (F4) Tonle Sap Fault Zone; (F5) Đà Lat-Bianhe Fault Zone; (F6) Điên Biên Phú Fault Zone; (F7) Changshan-Da Nang Fault Zone; (F8) Lanjiang Fault Zone; (F9) Ailaoshan-Red River Fault Zone; (F10) Xianshuihe-Xiaojiang Fault Zone; (F11) Lancang-Jinghong Fault Zone.

Batholith. We discuss these results of dating in the context of regional tectonic evolution.

\section{Dating Methods, Specimens, and Results}

2.1. Dating Methods. The U-Pb zircon age dating of monzonitic granite samples selected from the Mengku-Douge research area in Lincang segment (Figures 2 and 3) was designed and completed in the Institute of Geology and Geophysics, Chinese Academy of Sciences. Jobs of single zircon grain micro-area $\mathrm{U}-\mathrm{Pb}$ geochronological analysis were taken through Laser Ablation Inductively Coupled Plasma Mass Spectrometry (LA-ICPMS) of 7500a-type producted by Agilient Co. Ltd., with which the laser beam diameter is $60 \mu \mathrm{m}$, the erosion frequency is $8 \mathrm{~Hz}$, the energy density is $15 \sim 20 \mathrm{~J} \cdot \mathrm{cm}^{-2}$, the erosion time is about $60 \mathrm{~s}$. For detailed 


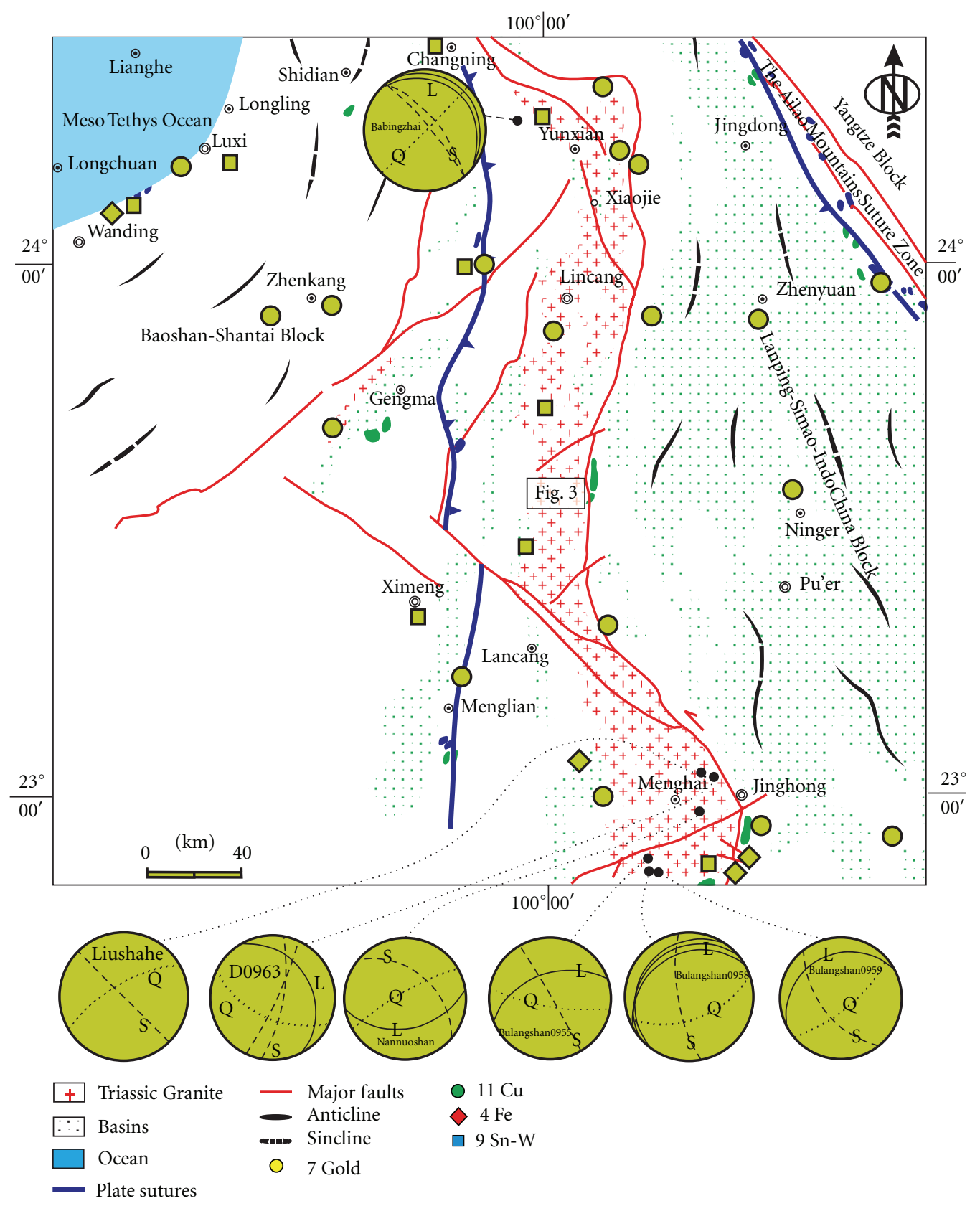

Figure 2: Regional map of Indian Period and research locality in western Yunnan. The distribution of metal deposits also indicates that there is an important boundary along the Lincang Granite Batholith. Stereographic maps of lower hemisphere projection indicating the initial occurrence of Lincang granite Batholith are also plotted in the regional map. L, S, Q refer to joints parallel to the initial foliation, parallel to the flow direction but upright to the initial foliation, upright to both the flow direction and initial foliation. Orientation of shear fractures can be generated by local stress system of the Batholith with emplacements [24].

analysis procedures, please see $\mathrm{Xu}$ et al. [32]. The Zircon $\mathrm{U}-\mathrm{Pb}$ isotope and the $\mathrm{U}$, Th data processing are finished by software Glitter4. 0 [33], and computing of $\mathrm{U}-\mathrm{Pb}$ concordia diagrams, weighted average ages and graphics were completed by software Isoplot3.0 [34].

\subsection{Specimens}

2.2.1. Specimen from Kunsai Quarries. The biotite monzonitic granite samples were selected from the Kunsai quarries to the east of Quannei-Douge migmatite rock belt (Figures 3 and 4(a)). The north part of the rock unit is plunged into the Jurassic basin (Figure 3). Field study shows that both the rock unit and the Jurassic basin have experienced a period of ductile transformation events. The microstructure study shows brittle deformed feldspar (Figures 4(b) and 4(c)), dynamically recrystallized quartz (Figure 4(c)), microdeflected biotite (Figure 4(d)), zircon grains with relatively intact crystal, long column, some 
TABLE 1: Isotopic age data for the Lincang Batholite in the earlier stage.

\begin{tabular}{|c|c|c|c|c|c|}
\hline $\begin{array}{l}\text { Lithologic } \\
\text { section }\end{array}$ & Lithology & $\begin{array}{c}\text { Measured objects and } \\
\text { methods }\end{array}$ & $\begin{array}{l}\text { Dating } \\
\text { results, } \mathrm{Ma}\end{array}$ & Sample positions & Testers and the time \\
\hline Xiaojie & Granite porphyry & Whole-rock (Rb-Sr) & $169 \pm 5$ & Laomaocun & Zhang et al., 2006 [25] \\
\hline Xiaojie & Monzonitic granite & Whole-rock $\left({ }^{87} \mathrm{Sr} /{ }^{86} \mathrm{Sr}\right)$ & 279 & Yun County & Chen, 1991 [26] \\
\hline Lincang & Biotite granite & Biotite $\left({ }^{40} \mathrm{Ar} /{ }^{39} \mathrm{Ar}\right)$ & $201.1 \pm 2.7$ & $\begin{array}{c}\text { Near the Lancangjiang } \\
\text { River }\end{array}$ & Dai et al., 1986 [27] \\
\hline Lincang & Monzonitic granite & Whole-rock (Rb-Sr) & 279 & Lincang & Chen, 1991 [26] \\
\hline Lincang & $\begin{array}{l}\text { Medium-grained equigranular } \\
\text { granodiorite }\end{array}$ & Whole-rock (Rb-Sr) & 263.8 & $\begin{array}{c}\text { Milestone along } \\
\text { Lincang-Mengku road } \\
\text { 327-387 km }\end{array}$ & Zhang et al., 1990 [28] \\
\hline Lincang & Unequal-sized biotite granite & Whole-rock (Rb-Sr) & 193 & Shangyun-Xiaotang & Zhang et al., 1990 [28] \\
\hline Lincang & Monzonitic granite & Whole-rock (Rb-Sr) & $275 \pm 59$ & Lincang & Liu et al., 1989 [18] \\
\hline Menghai & Monzonitic granite & Whole-rock $\left({ }^{87} \mathrm{Sr} /{ }^{86} \mathrm{Sr}\right)$ & 279 & Menghai & Chen, 1991 [26] \\
\hline Menghai & Monzonitic granite & Biotite $(\mathrm{Rb}-\mathrm{Sr})$ & 256 & Menghai & Wang, 1984 [29] \\
\hline
\end{tabular}
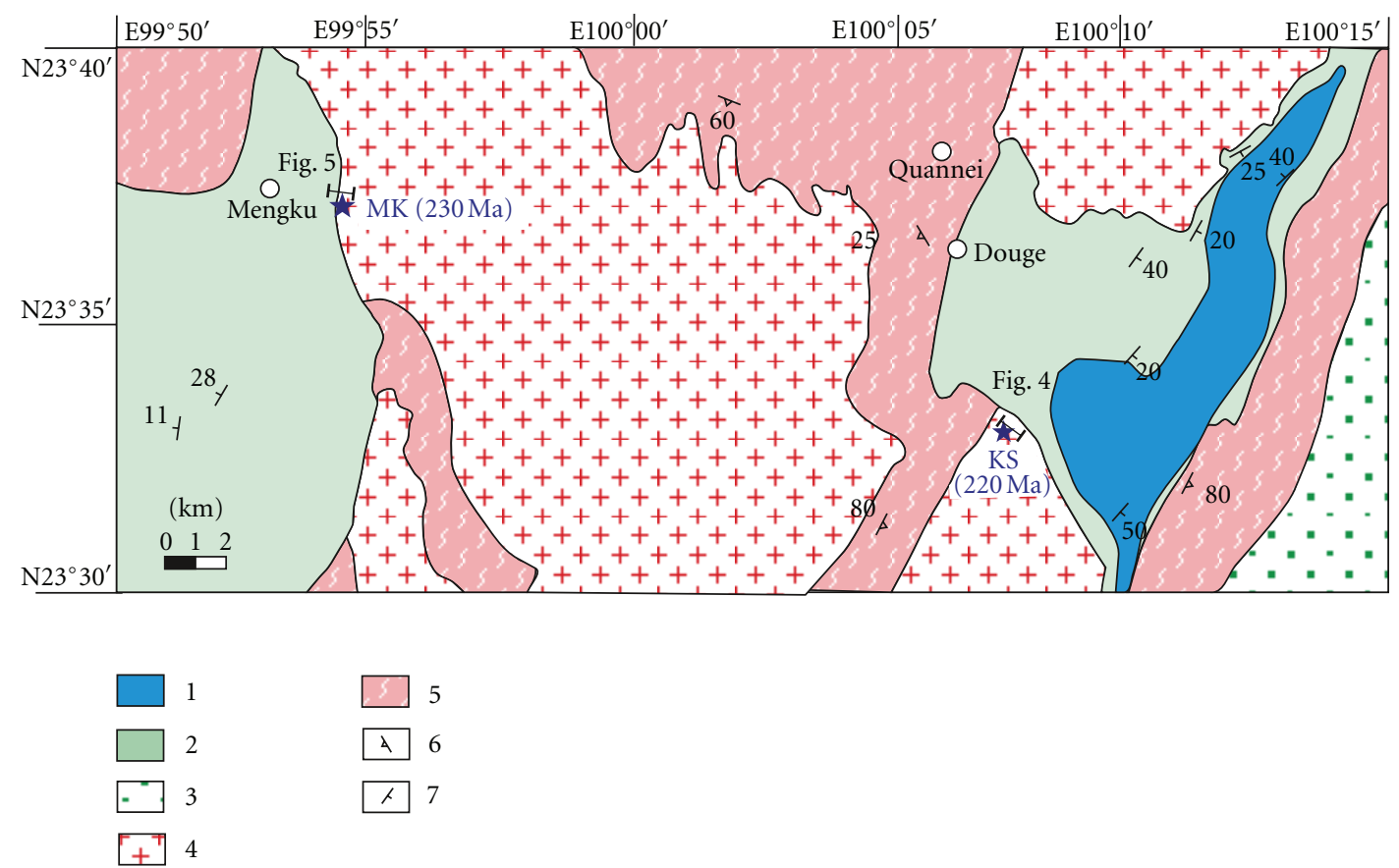

FIGURE 3: Geological sketch map in Mengku-Douge area (revised after [15-17, 30, 31]) (1) Area of ingression sea of the Meso-Tethys; (2) Jurassic terrigenous sediments; (3) Early Jurassic volcanic sedimentary rocks; (4) Lincang Triassic granite rock; (5) deep metamorphic wedge with local granodiorite quality migmatization Late Paleozoic; (6) schistosity occurrence; (7) bedding occurrence.

rounded output and a higher degree of porosity which is symbiotic to microcline grains (Figure 4(b)). The cathode luminescence $(\mathrm{CL})$ images show that the typical magmatic zircon characteristics are colorless and transparent here with oscillatory zoning, the length of about $120 \mu \mathrm{m}-420 \mu \mathrm{m}$ and the aspect ratio of 1.2 to 4.1 (Figure $4(\mathrm{e})$ ). Totally, for 22 points of 22 zircon grains of sample biotite granodiorite KS-2 from the Kunsai quarries we performed $\mathrm{U}-\mathrm{Pb}$ isotope analysis in order to statistically gain a feasible dating result (Figure 4(f)). All points were selected on the edge of long- column euhedral grains where the magmatic zircon oscillatory zoning is clear.
2.2.2. Specimens from Mengku Quarries. The monzonitic granite sample MK-4 is selected from the Mengku East Quarry at the eastern side of the Mengku Town in the Shuangjiang County, which separates Jurassic red clastic rocks with one bedding bottom granitic conglomerate by the paleo-weathering crust in between (Figures 5(a), 5(b), and $5(c))$. Figure 5(a) shows the position photo of the biotite monzonitic granite sample in the Mengku East Quarry. From the field outcrop, both granitic intrusion (lower left) and its weathering top can be found to be cleavaged which had been covered by the upper Jurassic red detrital sediments with terrigenous origin, namely, the Huakaizuo Formation. 


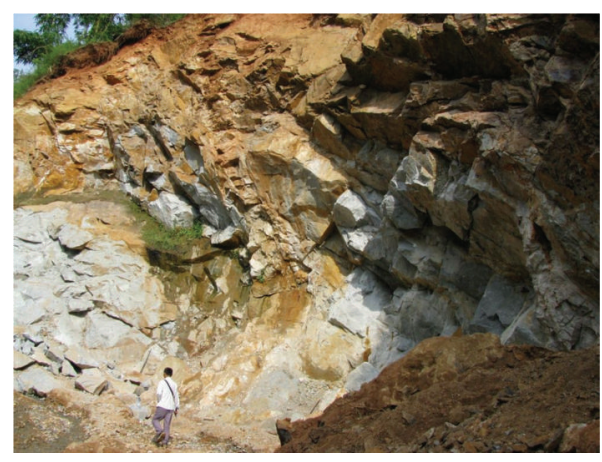

(a)

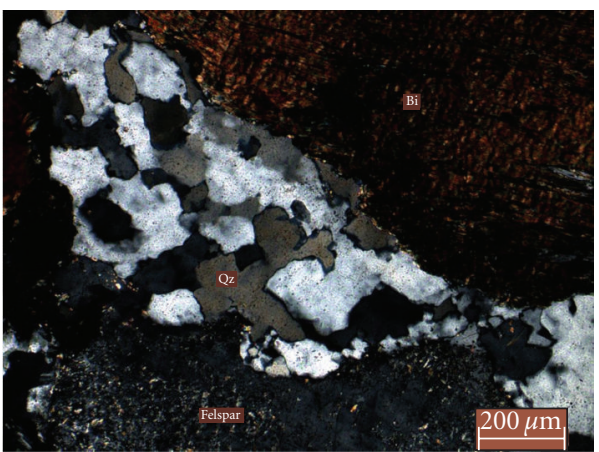

(c)

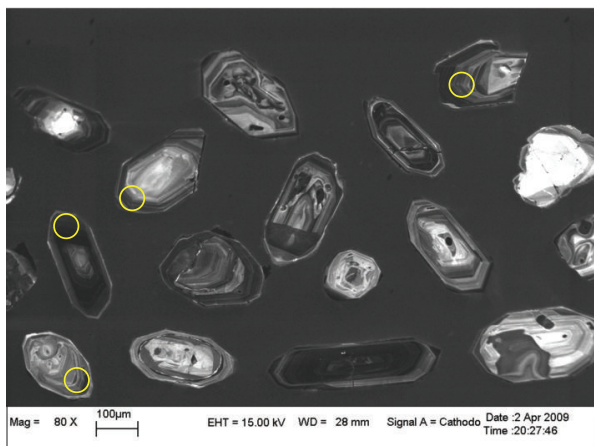

(e)

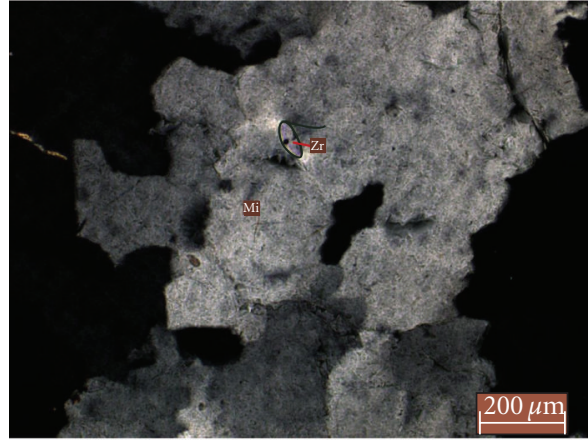

(b)

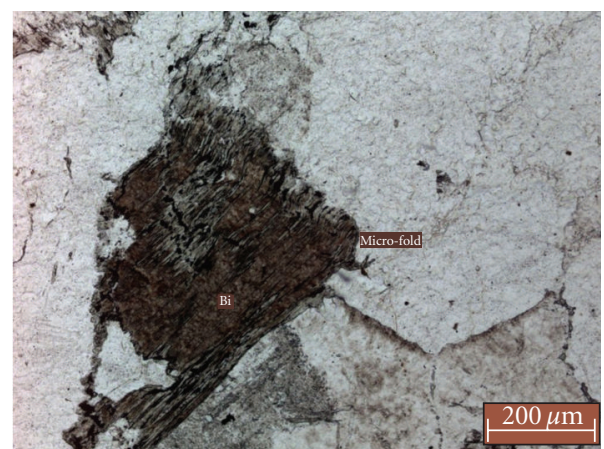

(d)

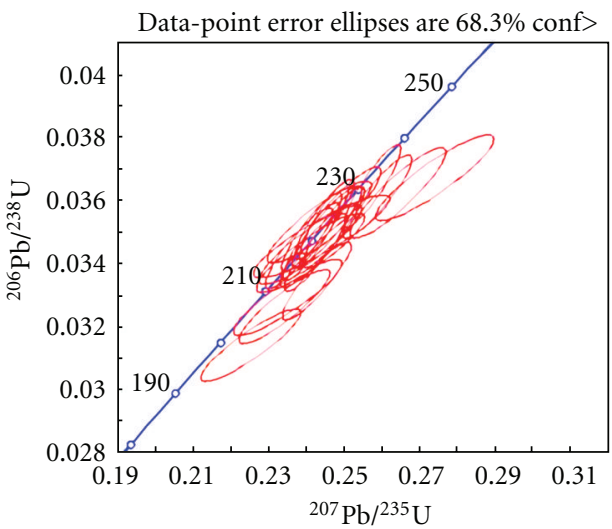

(f)

FIgure 4: Geochronological research of granite sample KS-2. (a) Position photo of the biotite monzonitic granite sample in the field of Kunsai Quarry. (b) The zircon grows together with the microcline CPL. (c) The microstructure of complete recrystallized quartz indicates the rock once experienced high-greenschist facies of deformation, CPL. (d) One biotite crystal is folded, PPL. (e) Magmatic zircon is shown by the SEM cathodoluminescence (CL) image. The circled area is deduced to form during the crystallization of granite and is just the measured area by laser-ICPMS (f) Zircon La-ICPMs U-Pb dating figure, and the average age is about $220 \mathrm{Ma}$.

The MK-4 zircon grains (Figure 5(d)) change greatly and have different shapes and sizes, such as long column, fan, and irregular granular. However, size of zircon grains is uniform with length between $90 \mu \mathrm{m}$ and $150 \mu \mathrm{m}$ and lengthwidth ratio in $1.1: 1-1.8: 1$. Zircon grains develop with quartz, plagioclase in rocks. The rock sample has been affected by weathering, showing retrograde metamorphism (Figure 5(e)). Characteristic oscillatory zoning of typical magmatic zircon is rendered on the cathode CL image. The idiomorphic degree of zircon is high, but some fragmented. On the sample of MK-4, 18 zircon grains and 18 points were analyzed by ICP-MS. Edge of the long-column idiomorphic or the chipped-hypidiomorphic zircon grains, and the clear zone of magmatic zircon oscillatory were always selected to perform the micro isotope analysis (Figure 5(f)).

2.2.3. Dating Results. As shown in Figure 4(f) and Table 2, the overall harmony values of KS-2 zircon age data range 


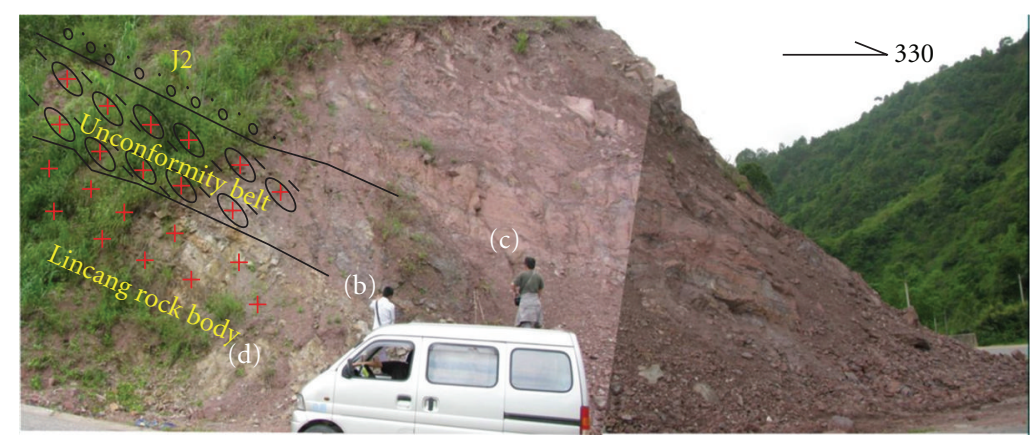

(a)

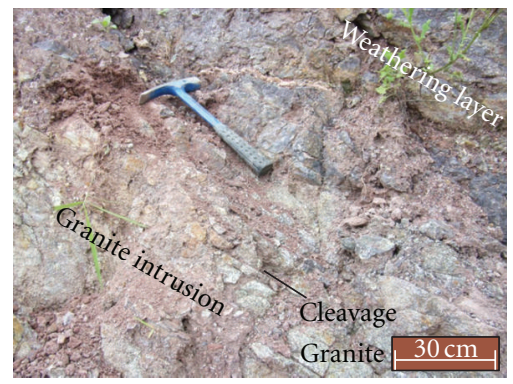

(b)

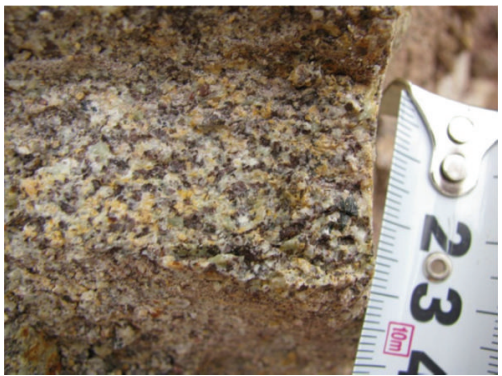

(d)

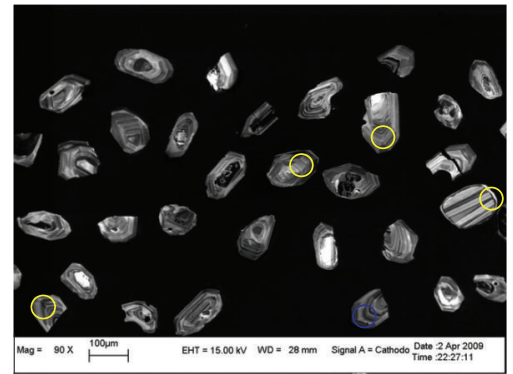

(f)

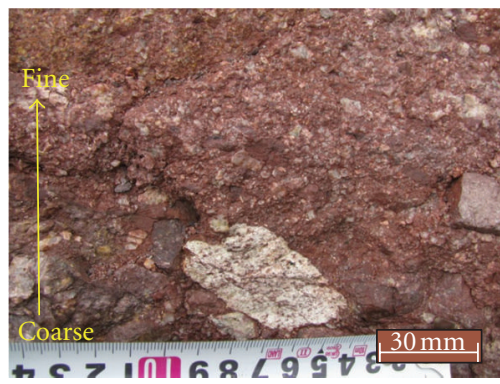

(c)

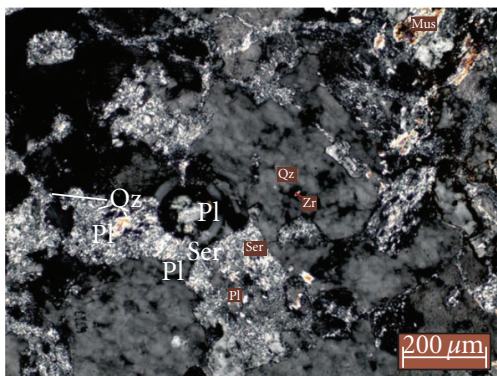

(e)

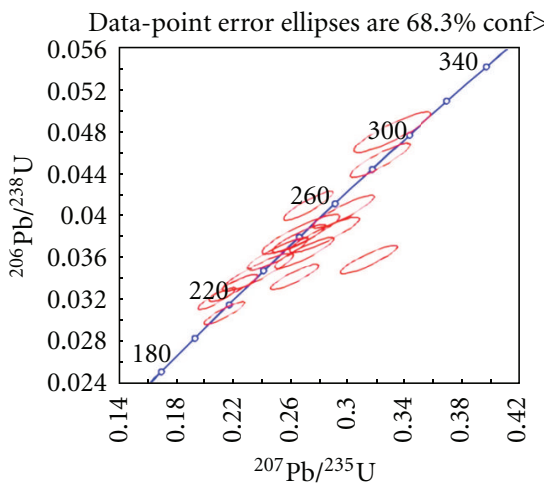

(g)

Figure 5: Geochronological research of the granite sample MK-4. (a) Position photo of the biotite monzonitic granite sample in a field Quarry of east Mengku. (b) Granitic intrusion (lower left) and its fossil weathering were cleavaged. (c) The red detrital material of terrigenous origin, Huakaizuo Formation in Jurassic, was normal gradational. (d) Granitic intrusions are selected as sample. (e) The micro characteristics of MK-4 and the zircon setting are shown. The zircon grains are associated with quartz and plagioclase and have been degraded by some weathering process, CPL, (f) Magmatic zircon is shown by the SEM cathodoluminescence (CL) image. The circled area is deduced to form during the crystallization of granite and is just the measured area by laser-ICPMS. (g) Zircon La-ICPMs U-Pb dating figure, and the average age is about $245 \mathrm{Ma}$. 


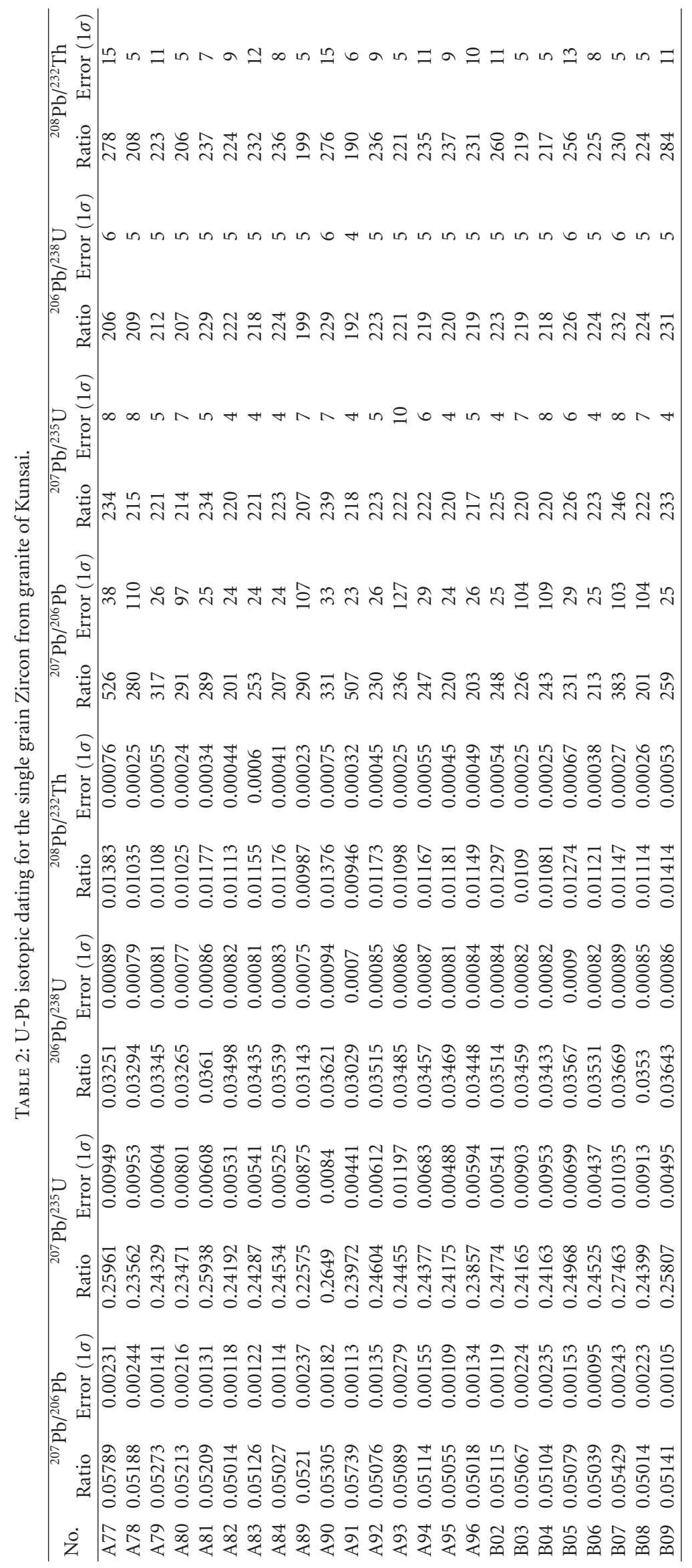




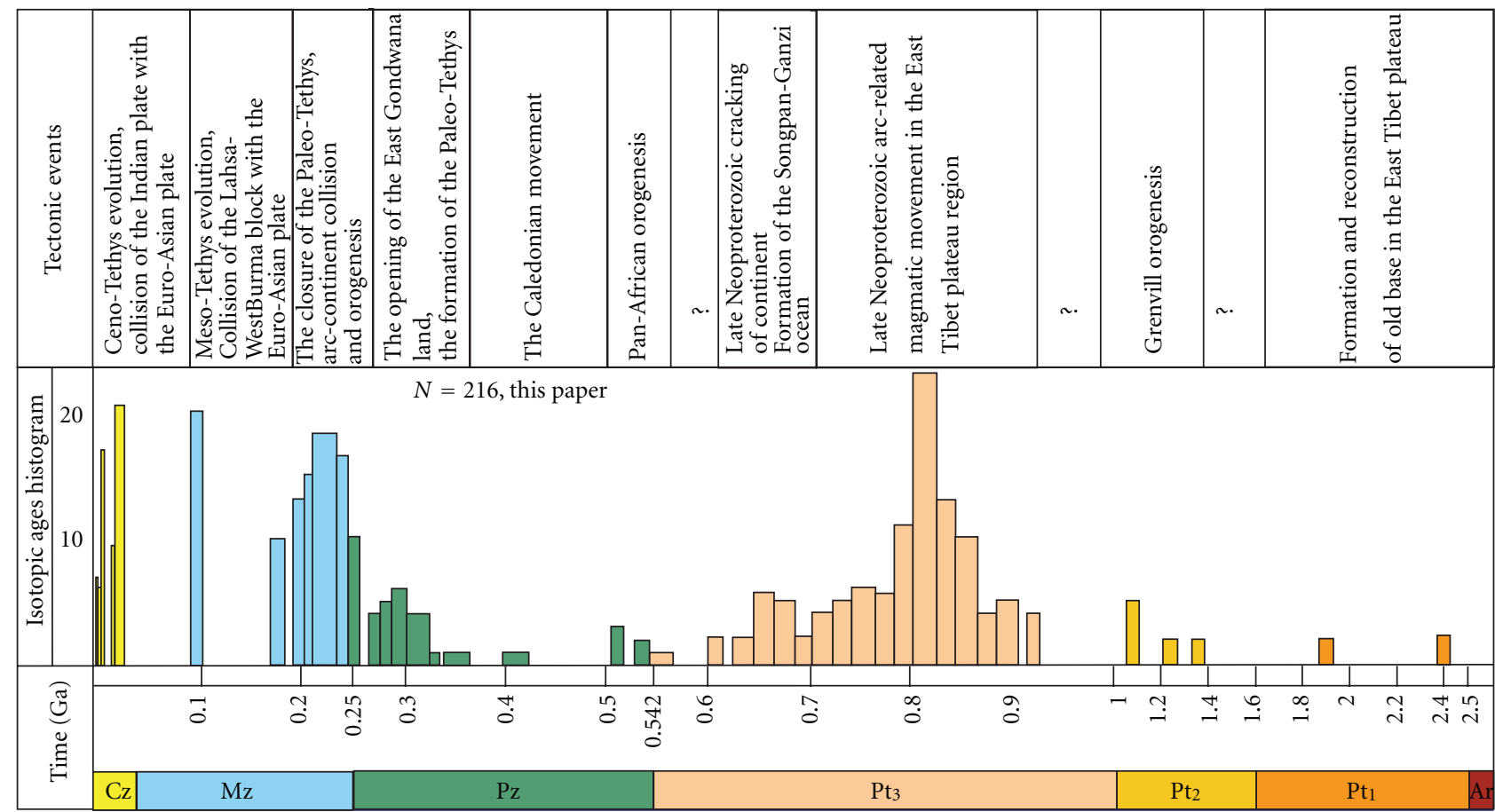

FIGURE 6: Isotopic age histogram showing the major tectonic event in the area east to the Tibet Peateau (after [8]).

from $195 \mathrm{Ma}$ to $245 \mathrm{Ma}$, but some of them are below the $\mathrm{U}-\mathrm{Pb}$ harmonic line and deviated from the harmony line. This is probably because the micro region selected is too close to the boundary of the zircon grain. Some zircon grains (Figure 5(f)) also have some cracks in and this may also affect the dating result. From the harmonic visible figure, zircon dating values are focused to a range from $210 \mathrm{Ma}$ to $230 \mathrm{Ma}$, and the average age is about $220 \mathrm{Ma}$. This means that the crystallization age of the Kunsai quarries biotite granite is about in the late Triassic Norian period.

As shown in Figure 5(g) and Table 3, the overall harmony values of MK-4 zircon age data range between $190 \mathrm{Ma}$ and $315 \mathrm{Ma}$. The values are somewhat scattered mainly because the granite of the Mengku quarries has been heavily weathered (Figure 5(d)). During the weathering process, chemical bonds of $\mathrm{ZrO}_{2}$ in zircon grains of our MK-4 sample would be broken. Therefore, some zircon isotope escaped. The average age of $245 \mathrm{Ma}$ might indicate that the late Permian to early-middle Triassic magmatic event happened in the Mengku Quarries area of the Lincang Batholith.

\section{Tectonic Implications}

Previous petrological and geochemical studies [18, 26, 28, 35 ] indicate that the Lincang granite mainly shows two types of granite with an initial strontium isotope ratio ranging from 0.71 to 0.78 and therefore it belongs to S-type granite and once may have been formed in an environment of tectonic collision. Combined with previous chronological data, we propose a three-stage model on the tectonic evolution between late Permian and Jurassic (Figure 6).
(1) Regional Collision and Contraction before the Formation of the Lincang Batholith. Before the formation of the Lincang Batholith, the Paleo-Tethys Ocean and many intraoceanic islands distributed between the Baoshan and the LanpingSimao-Indosinian blocks [36]. In a regional contractional environment of subduction and collision, it is extremely common to find folding, thrusting, and uplifting phenomena (Figure 7(a)).

(2) Time Heterogeneity of In Situ Hybrid of the Lincang Batholith. The Lincang Batholith was controlled by one deep-seated fault along the Lancang Jiang River and proposed in situ hybrid origin of the Batholith in the early to middle Triassic collision between the Baoshan-Shantai and Lanping-Simao-Indochina Blocks [16]. Our study shows an ununiform law result in the aspect of mixing time of the Batholith (Figure 7(b)). The intrusion time in the east Qunsai area was later than in the Mengku area, indicating that the regional contraction in Mengku area was weakened or stopped, and triggered magma poured at $230 \mathrm{Ma}$, however, the contraction pattern may still remain in the Qunsai area to the east.

(3) Tectonic Denudation and Regional Exhumation Happened between Late Triassic and Middle Jurassic, Which Is Supported by $201 \mathrm{Ma}$ Biotite ${ }^{40} \mathrm{Ar} /{ }^{39} \mathrm{Ar}$ Age from the Lincang Batholith [27]. This paper research shows that the upper part of the Lincang Batholith experienced long-term denudation, resulting in the development of the weathering crust (Figure 7(a)). The upper crust is the Jurassic Huakaizuo Formation, characterized by carbonate rocks of shallow sea facies, together with some volcano clastic rocks (Figure 5(b)). 


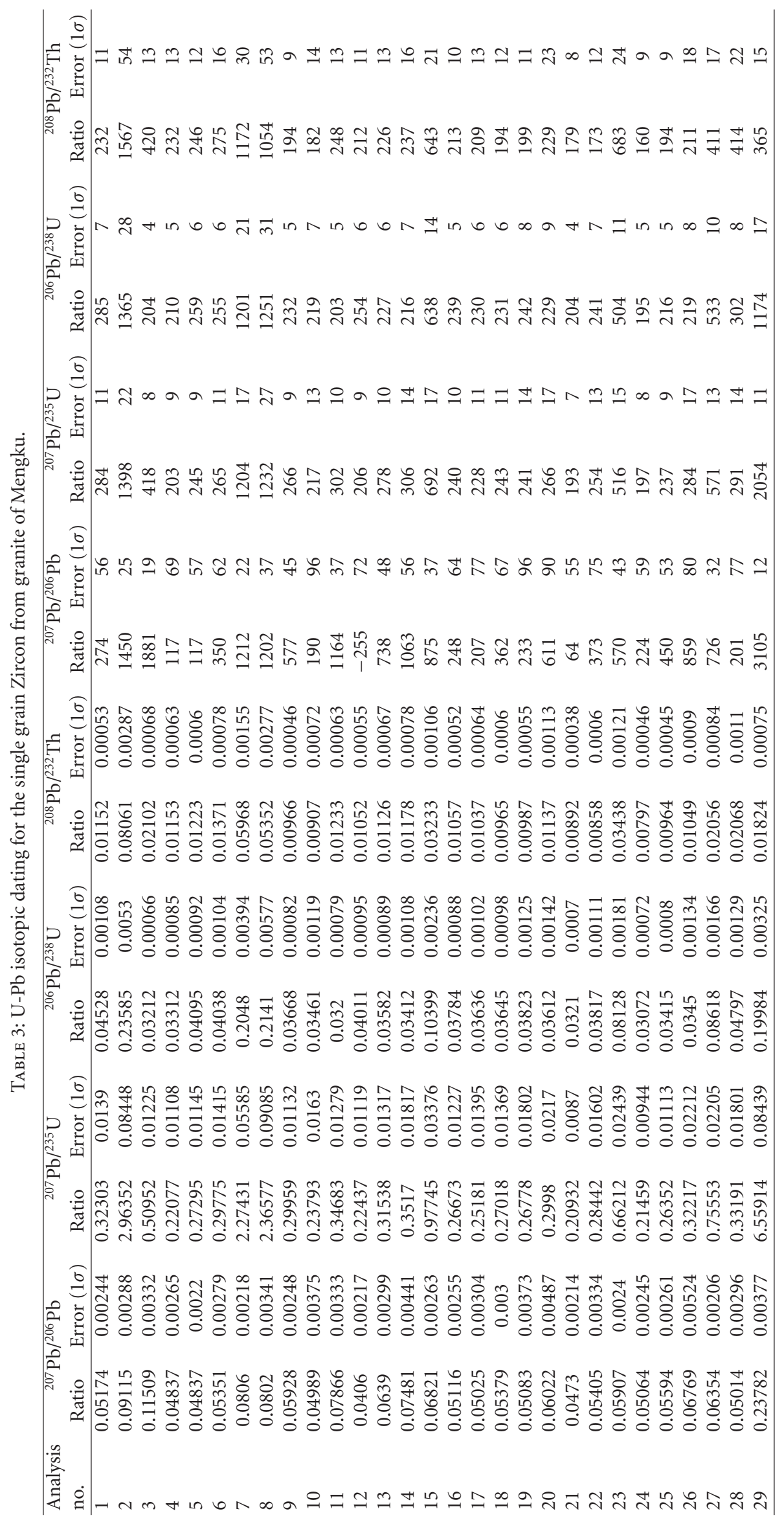




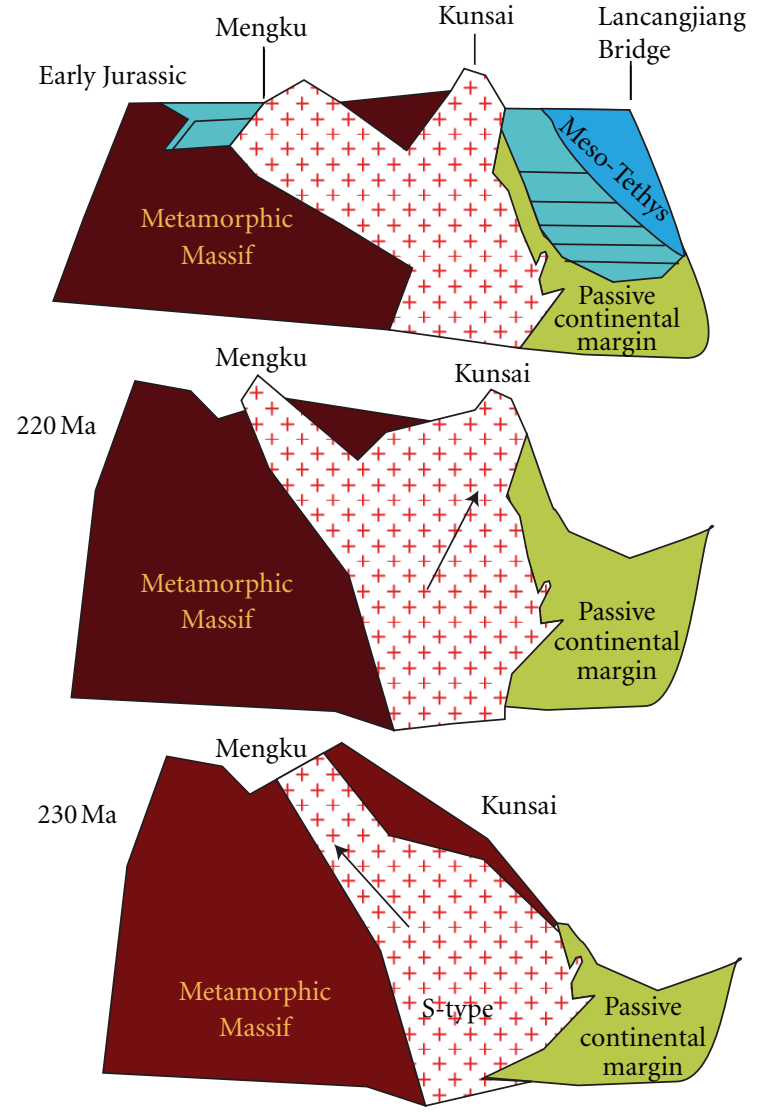

FIGURE 7: Formation and tectonic evolution model for the Lincang Batholith.

Unconformity relationship is shown between the Batholith and the Huakaizuo Formation (Figures 3, 5(a), 5(b), 5(c), and $7(\mathrm{c})$ ). Apparently, the Meso-Tethys expansion also happened in this era and left some effect in the Lincang Area.

\section{Acknowledgments}

The authors appreciate sincerely both the field research and inner discussion together with Professor Yong-Qing Chen from China University of Geosciences (Beijing), Research Fellow Ying-Xiang Lu from Yunnan Bureau of Geology and Mineral Resources, and Research Fellow Fang-Cheng Lin from Chengdu Institute of Geology and Mineral Resources. The authors thank Dr. Pengfei Li from University of Queensland for his perfect academic revision of the paper. The research was supported by the China Geology Survey (no. 200811008, no. 1212011121188), the Ministry of Science and Technology (no. 2006BAB01A03-3), the Chinese National Natural Foundation (no. 90814006) of the People's Republic, and the China University of Geosciences in Beijing (no. 2-92001-280).

\section{References}

[1] J. Q. Huang and B. W. Chen, The Evolution of the Tethys in China and Adjacent Regions, Geological Publishing House, Beijing, China, 1987.
[2] P. Jian, D. Liu, A. Kröner et al., "Devonian to Permian plate tectonic cycle of the Paleo-Tethys Orogen in southwest China (II): insights from zircon ages of ophiolites, arc/back-arc assemblages and within-plate igneous rocks and generation of the Emeishan CFB province," Lithos, vol. 113, no. 3-4, pp. 767784, 2009.

[3] H. D. Klemme and G. F. Ulmishe, "Effective petroleum source rocks of the world: stratigraphic distribution and controlling depositional factors," AAPG Bulletin, vol. 75, no. 12, pp. 1809$1851,1991$.

[4] G. T. Pan, Z. L. Chen, and X. Z. Li, Geological Structure Formation and Evolution of East Tethys, Geological Publishing House, Beijing, China, 1997.

[5] G. T. Pan, H. X. Zheng, Y. R. Xu et al., "A preliminary study on Bangong Co-Nujiang Suture," in Editing Committee of Geological Memoirs of Qinghai-Xizang Plateau(12)-Geological Tectonics of "Sanjiang", pp. 229-242, Geological Publishing House, Beijing, China, 1983.

[6] X. Wang, I. Metcalfe, P. Jian, L. He, and C. Wang, "The Jinshajiang-Ailaoshan Suture Zone, China: tectonostratigraphy, age and evolution," Journal of Asian Earth Sciences, vol. 18, no. 6, pp. 675-690, 2000.

[7] A. M. C. Sengor and U. J. Botum, "The Tethys orogenic system: an introduction," in Tectonic Evolution of the Tethyan Region, A. M. C. Sengor, Ed., pp. 1-22, Kluwer Academic, Boston, Mass, USA, 1989.

[8] Q. Yan, Z. Wang, S. Liu et al., "Opening of the Tethys in southwest China and its significance to the breakup of East Gondwanaland in late Paleozoic: evidence from SHRIMP U$\mathrm{Pb}$ zircon analyses for the Garze ophiolite block," Chinese Science Bulletin, vol. 50, no. 3, pp. 256-264, 2005.

[9] P. A. Ziegler, Evolution of Laurussia: A Study in Late Palaeozoic Plate Tectonics, Kluwer Academic, Dordrecht, The Netherlands, 1989.

[10] B. P. Liu, Q. L. Feng, C. Chonglakmani et al., "Framework of paleotethyan archipelago ocean of western Yunnan and its elongation towards north and south," Earth Science Frontiers, vol. 9, no. 3, pp. 161-171, 2002.

[11] C. S. Hutchison, Geological Evolution of Southeast Asia, vol. 13 of Oxford Monographs on Geology and Geophysics, Clarendon Press, Oxford, UK, 1989.

[12] H. R. Wu, C. A. Boulter, B. Ke et al., "The ChangningMenglian suture zone: a segment of the major CathaysianGondwana divide in Southeast Asia," Tectonophysics, vol. 242, no. 3, pp. 267-280, 1995.

[13] H. Y. Zhang and J. L. Liu, "Plate tectonics and mineralization of the Tethyan ophiolite in the southern Sanjiang and IndoChina peninsular area," Earth Science, Journal of China University of Geosciences, vol. 36, no. 2, pp. 262-276, 2011 (Chinese).

[14] P. F. Fan, "Accreted terranes and mineral deposits of Indochina," Journal of Asian Earth Sciences, vol. 18, no. 3, pp. 343-350, 2000.

[15] M. J. Lin, "The volcanic rock sequence and its geological age along the bank of Lancang Jiang, West Yunnan" (Chinese), See: Geology Papers of Qinghai-Tibet Plateau (13)-Rocks in Sanjiang Area, pp. 151-158, 1983.

[16] J. Y. Xiong, Y. M. Lin, and S. R. Qin, "A preliminary study on the genesis and the basic characteristics of the Lincang magmatic complex" (Chinese), See: Geology Papers of Qinghai-Tibet Plateau (13)-Rocks in Sanjiang Area, pp. 119, 1983. 
[17] S. Y. Yu, K. Q. Li, Y. P. Shi, and H. H. Zhang, "A study on the granodiorite in the middle part of Lincang granite batholiths," Yunnan Geology, vol. 22, no. 4, pp. 426-442, 2003.

[18] C. S. Liu, J. C. Zhu, X. S. Xu, X. J. Chu, D. K. Cai, and P. Yang, "Study on the characteristics of Lincang Composite Granite Batholith in West Yunnan," Yunnan Geology, vol. 8, no. 3-4, pp. 189-212, 1989 (Chinese).

[19] X. L. Li, "Basic characteristics and formation structural environment of Lincang Composite granite batholiths," Yunnan Geology, vol. 15, no. 1, pp. 1-18, 1996 (Chinese).

[20] J. C. Chen, "Discussion on the age division and the selects of isotopic age determination for granitic rock in Western Yunnan," Yunnan Geology, vol. 6, no. 2, pp. 101-113, 1987 (Chinese).

[21] X. X. Mo, S. Y. Shen, Q. W. Zhu et al., Volcanic-Ophiolite and Mineralization of Middle-Southern Part in Sanjiang Area of Southwestern China, Geological Publishing House, Beijing, China, 1998.

[22] D. L. Zhong, Paleo-Tethys Orogenic Zone in Western Yunnan and Western Sichuan, Science Press, Beijing, China, 1998.

[23] A. Socquet and M. Pubellier, "Cenozoic deformation in western Yunnan (China-Myanmar border)," Journal of Asian Earth Sciences, vol. 24, no. 4, pp. 495-515, 2005.

[24] R. G. Park, Foundations of Structural Geology, Chapman \& Hall, New York, NY, USA, 2nd edition, 1989.

[25] C. H. Zhang, J. S. Liu, D. L. Liu, and S. Yang, "Geological, geochemical characteristics, age and tectonic setting of Laomaocun small rockbody in South Lancangjiang Zone," ACTA Mineralogica Sinica, vol. 26, no. 3, pp. 317-324, 2006.

[26] J. C. Chen, "Characteristics of $\mathrm{Pb}, \mathrm{Sr}$ isotopic compositions in west Yunnan granites: discussion on the age and nature of the basement in west Yunnan," Scientia Geologica Sinica, vol. 2, pp. 174-183, 1991.

[27] T. M. Dai, B. Q. Zhu, Y. Q. Zhang, Z. P. Pu, Q. F. Zhang, and A. S. Hong, "Collision and thermial history of Indian-SandalandEurasian Plates as implicated by ${ }^{40} \mathrm{Ar} /{ }^{39} \mathrm{Ar}$ age spectra of granodiorites," Geochimica, vol. 15, no. 2, pp. 97-107, 1986.

[28] Y. Q. Zhang, Y. W. Xie, and J. W. Wang, "Rb and Sr isotopic studies of granitoids in Tri-river region," Geochimica, vol. 19, no. 4, pp. 318-326, 1990 (Chinese).

[29] W. Y. Wang, "Rb-Sr isotopic Data," Yunnan Geology, vol. 3, no. 1, pp. 79-96, 1984 (Chinese).

[30] Yunnan Bureau of Geology and Mineral Resources (YBGM), Geoogical Map of the Jinggu Sheet at a Scale of 1:200, 000, Ministry of Geology and Mineral Resources, Beijing, China, 1983.

[31] Yunnan Bureau of Geology and Mineral Resources (YBGM), Geological Map of the Gengma Sheet at a Scale of 1:200, 000, Ministry of Geology and Mineral Resources, Beijing, China, 1985.

[32] P. Xu, F. Wu, L. Xie, and Y. Yang, "Hf isotopic compositions of the standard zircons for U-Pb dating," Chinese Science Bulletin, vol. 49, no. 15, pp. 1642-1648, 2004.

[33] S. E. Jackson, N. J. Pearson, W. L. Griffin, and E. A. Belousova, "The application of laser ablation-inductively coupled plasma-mass spectrometry to in situ $\mathrm{U}-\mathrm{Pb}$ zircon geochronology," Chemical Geology, vol. 211, no. 1-2, pp. 4769, 2004.

[34] K. Ludwig, Isoplot/Ex version 2.0: A Geochronological Tool Kit for Microsoft Excel, Geochronology Center Berkeley, Special Publication, 1999.

[35] B. W. Chappell and A. J. R. White, "I- and S-type granites in the lachlan fold belt, Southeast Australia," in Geology of
Granites and their Metallogenetic Relations, X. Keqin and T. Guangchi, Eds., pp. 72-78, Science Press, Bejing, China, 1982.

[36] B. P. Liu, Q. L. Feng, N. Q. Fang et al., "Tectonic evolution of Paleo-Tethys Poly-island-ocean in Changning-Menglian and Lancangjiang Belts, south-western Yunnan, China," Earth Science, Journal of China University of Geosciences, vol. 18, no. 5, pp. 529-539, 1993 (Chinese). 

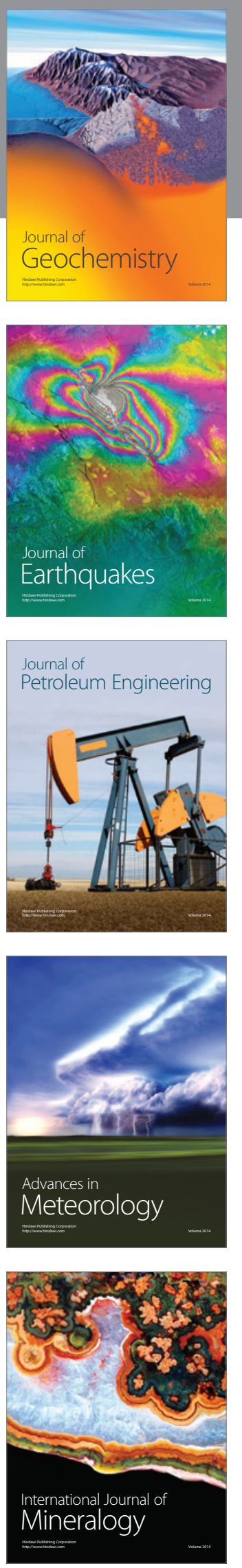
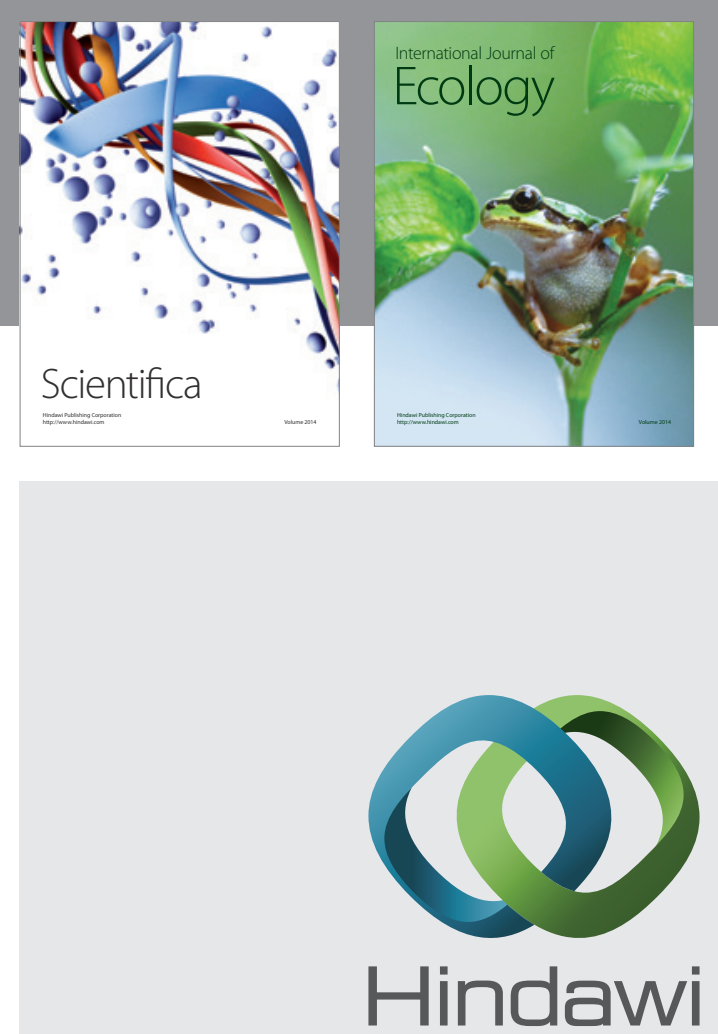

Submit your manuscripts at http://www.hindawi.com
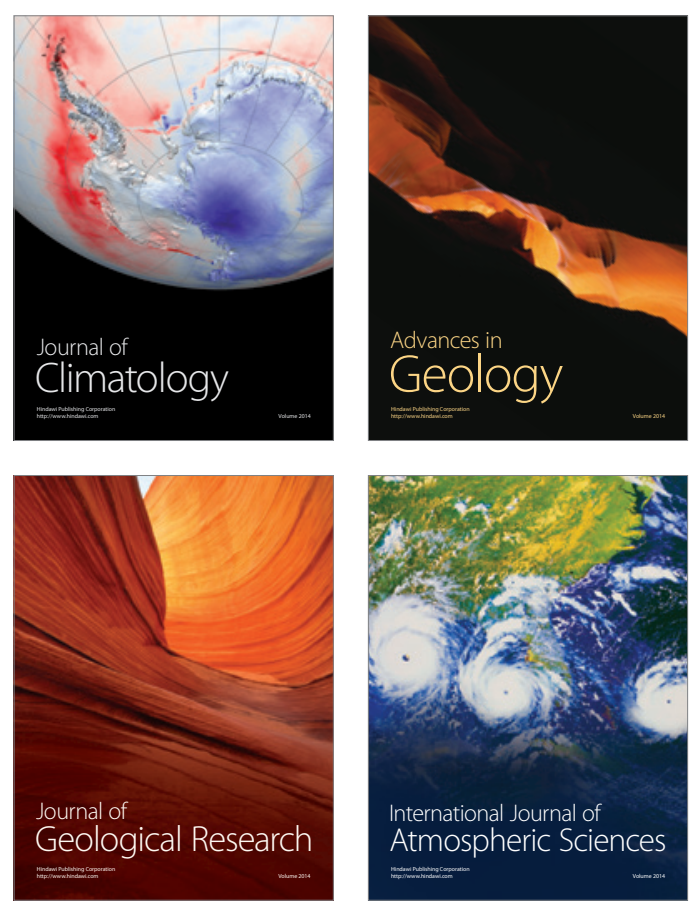
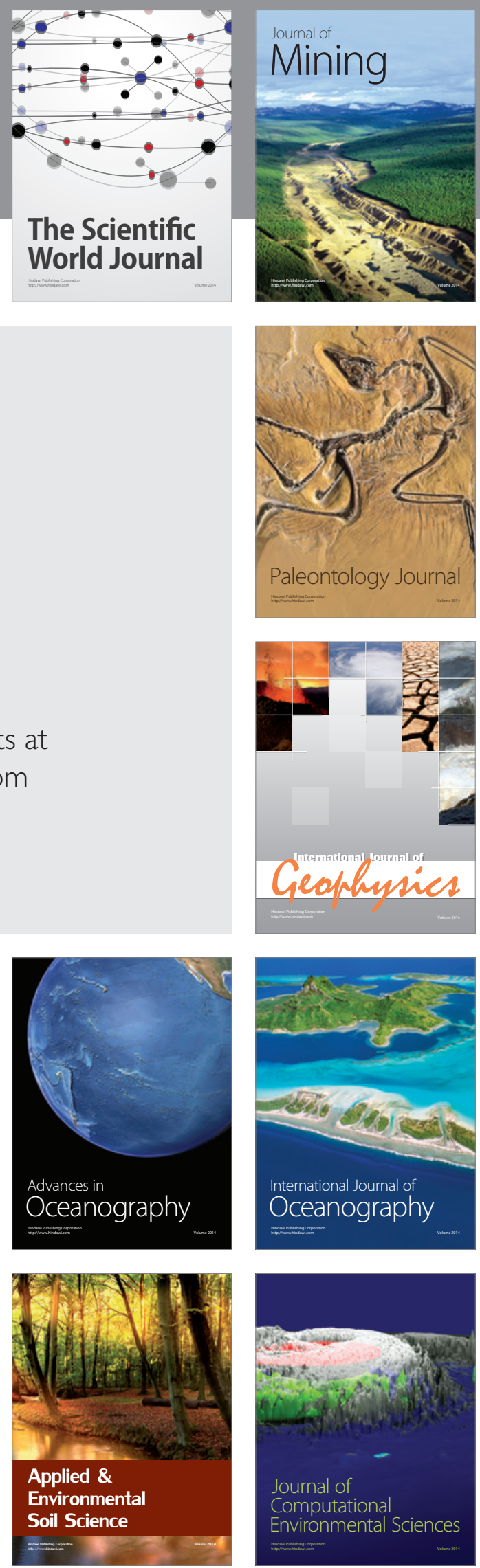